\title{
3 Phase Monitoring and Control Control Systems based on Labview
}

\author{
Fanny Doringin \\ Department of Computer \\ Engineering \\ Manado State Polytechnic
}

\author{
Marson James Budiman \\ Department of Computer \\ Engineering \\ Manado State Polytechnic
}

\author{
Stephy Walukow \\ Department of Computer \\ Engineering \\ Manado State Polytechnic
}

\begin{abstract}
Large power consumers or consumers who have their own distribution substations, such as Hotels, Offices, Shopping Centers, Industries, etc. Installation is connected with 3 phase electricity, which includes phase $\mathrm{R}$, phase $\mathrm{S}$ and phase $\mathrm{T}$. In planning and installing electrical installations carried out by installer (Electrical expert) always refers to the design of loads connected in $\mathrm{R}, \mathrm{S}$ and $\mathrm{T}$ phases, which are balanced (equally large), but in the operation (ON / OFF) of the electrical load the balance of the load cannot be adjusted for each phase, because operation (ON / OFF) adjusted to the needs of electrical equipment installed in each phase, so that the load is not balanced. Unbalanced loads in each phase can cause electrical power losses. Electricity losses will be even greater, if additional loads or the development of electrical installations are carried out without regard to the initial design of installation. In this study a simulation of a monitoring and control system will be created automatically as a study material to minimize the occurrence of phase load imbalance. The control system will work automatically to monitor and control supply to the load. Besides that, this control system can also detect if one or two phases are lost (OFF), where the system will provide information to the user in the form of an alarm, which shows that there has been a loss of phase, so that users can carry out the overall power outage. avoid the occurrence of large power losses. The method used in making the system is a method of research and development, with the stages including the study of literature, field studies to obtain data relating to the making of the system. The next stage is designing software that is simulated through the Lab View program. The next step is to test the work of the control system based on a system algorithm made through program simulations. The results of the tests were carried out, when the system was not burdened and burdened, for example the load detected in Phase $\mathrm{R}$ was 1.01 Ampere, in Phase $\mathrm{S}$ as basic as 1.5 Amperes and in Phase $\mathrm{T}$ of 1 Ampere, the system would automatically move one of the electricity lines from Phase $\mathrm{R}$ to one of the paths of Phase T, so that the overload in Phase R is overcome by Phase T. Besides that, when indicated there is one phase missing, the system will inform the alarm indicator and display on the monitor.
\end{abstract}

\section{Keywords}

Simulation, control system, load control, Labview

\section{INTRODUCTION}

Unbalanced loads in phase $\mathrm{R}, \mathrm{S}$ and $\mathrm{T}$ will make a current flow in the neutral point. The greater the unbalanced load will also make the greater the current flowing at the neutral point. This makes electric power wasted or power losses occur. In addition to power losses, this unbalanced load will contribute to the distribution of power by the transformer to a lesser extent. To minimize the occurrence of electrical power losses caused by the operation of unbalanced loads and over time the development of electrical installations takes place without regard to the initial installation electrical installation planning, and if there is a loss of one or two electrical phases, a control system that can detect and regulate load in phase $R$, phase $S$ and phase $\mathrm{T}$ are relatively balanced, besides that the Control system created can also provide information to the user if there is a loss of one or two phases in order to avoid power losses. The integrated system in making unbalanced load loss control systems uses the Lab View and Arduino Unoyang controllers to function as the overall working regulator of the system [1] [2], current sensors that function as detecting changes in load current [3], voltage sensors that function to detect phase loss [4], a program algorithm (flowchart) that functions for steps to be taken in making programs and system modeling [5] [6]. To run the system, it takes a program that is embedded into the Arduino Uno microcontroller, where the software used to create the program is the IDE View Lab, with reference to the flowchart made [7].

\section{METHODOLOGY}

In producing an automatic system model of unbalanced power losses, a system design process is carried out which includes designing a system model, designing hardware, designing software, testing the system through a simulation program to obtain data in connection with system work.

\subsection{Designing a System Model}

The design of the system model aims to describe and determine the components that support the work of the control system of the automatic control system, the electrical power losses are unbalanced in the phase R, S, T.

The system model is shown in Figure 1, with the job description as follows:

1. Flow Sensor, serves as a detector of changes in load current on the 3 phase network.

2. The phase detection sensor is lost, it functions to detect phase loss from the 3 phase system.

3. Lab View and Arduino Uno controllers, which function as media controllers in the process of regulating load supply, using 2 controllers that function as slave masters.

4. Relay, functions as a breaker and electrical supply connector to load. 


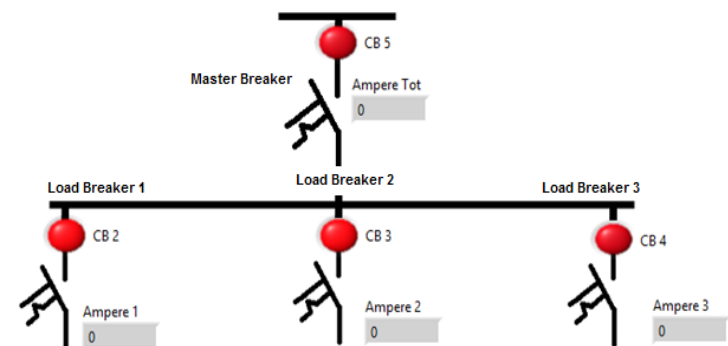

Fig 1: Wiring Diagram

\subsection{Design and Manufacture of R, S, T load control devices}

The design of the system simulation is made using the Lab View simulation program, by arranging the supporting components of the control system according to their functions and needs in the system. Figure 2 shows the system design created. When the load is detected in a balanced state, where the amount of electricity consumption is detected through the current sensor from each phase, both phase $\mathrm{R}$, phase $\mathrm{S}$ and Phase $\mathrm{T}$ are equal

\section{RESULT AND DISCUSSION}

\subsection{Testing When Phase $R, S$ and $T$ are not loaded}

Figure 2 shows the test results when the system detects that inter-phase loads are not loaded. When the load is detected in a balanced state, where the amount of electricity consumption is detected through the current sensor from each phase, both phase $\mathrm{R}$, phase $\mathrm{S}$ and Phase $\mathrm{T}$ are equal

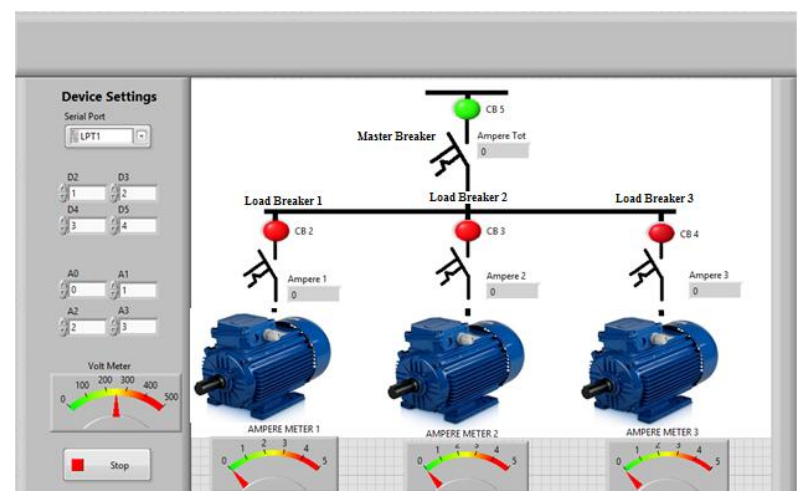

Fig 2: system testing without load

\subsection{Testing When Phase $R, S, T$ is currently loaded}

When the system detects that the load on phase $\mathrm{T}$ is greater than the load on phase $\mathrm{R}$, while the load on phase $\mathrm{R}$ is greater than the load on phase $S$, then the system will automatically deactivate the relay on one of the lines to the load from phase $\mathrm{T}$, and be replaced with a relay reserves of phase $\mathrm{S}$ to supply the load on the replaced $\mathrm{T}$ line, to keep the system relatively balanced. In addition, the system will inform the monitor that one path to the load of phase $\mathrm{T}$ has been replaced by one of the $\mathrm{S}$ phase tie lines to overcome the overload of the $\mathrm{T}$ phase. Figure 3 shows a test when phase $\mathrm{T}$ is greater than phase $\mathrm{R}$ and phase $\mathrm{R}$ is more big from phase $\mathrm{S}$.

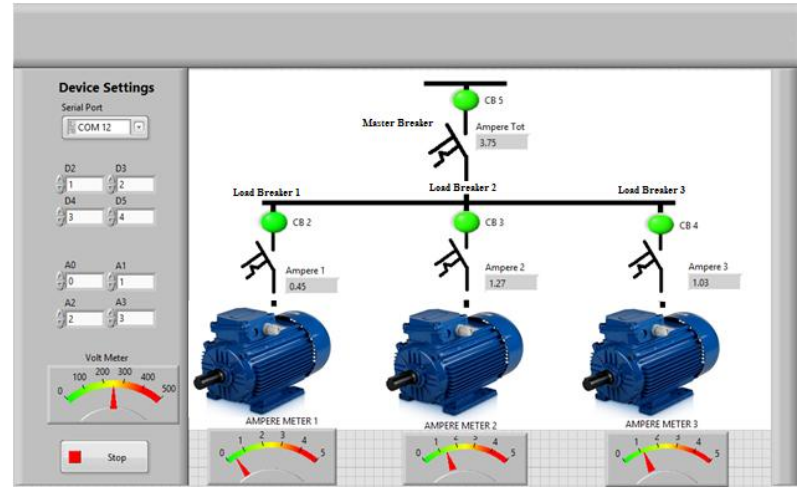

Fig 3: system testing when burdened

\subsection{Measurement of Electric Current}

The process of testing the current sensor circuit shows that there are 4 test points, where the output voltage depends on the change in electric current from the load. The test is carried out by assuming that the air conditioning equipment used is $1 / 2$ PK capacity. The test results of the current sensor circuit are shown in Table 1.

\section{Table 1. measurement results of used current}

he results of testing the current sensor in Table 1 show that there are 4 stages of current testing carried out. Current testing is carried out using an ammeter to measure the amount of current consumed by air conditioning.

a. The first test is carried out when the AC is inactive, where the current is 0 Ampere. The output of the current sensor that is carried out using the Volt meter (V1) measuring instrument is $2.49 \mathrm{Volt}$. From the results of the test there is a difference of 0.01 volt from the output data issued by the factory where the data is 2.5 volts when the sensor is not banned, so the magnitude of the error between factory data and the test data is:

$$
\begin{gathered}
\text { Error }(\%)=\frac{\text { sensor data current-measurement data }}{\text { sensor data cirrent }} \times 100 \% \\
=\frac{2,5-2,49}{2,5} \times 100 \% \quad=0,4 \%
\end{gathered}
$$

Voltage testing is done by using a V2 measuring device at the output after passing through the voltage divider circuit and rectifier circuit showing the number 1.24 Volt. Theoretically the output voltage of the voltage divider circuit is as follows:

$$
V_{\text {Output }}=\frac{R 2}{R 2+R 1} x \text { vin }
$$

Where is the amount of $\mathrm{R} 1=\mathrm{R} 2=1 \mathrm{k} \Omega$, so that

$V_{\text {Output }}=\frac{1000}{1000+1000} \times 2,49$

$=0,5 \times 2,49$

$=1,24$ Volt .

The amount of error between the results of calculations and the test results is as follows:

$$
\begin{aligned}
& \text { Error }(\%)=\frac{\text { calculation data-measurement data }}{\text { camculation data }} \times 100 \% \\
& =\frac{1,24-1,24}{1,24} \times 100 \% \\
& =0 \%
\end{aligned}
$$

The voltage test carried out by using a V3 measuring device at the output after passing through the op-amp amplifier circuit 
shows a number of 2.48 Volt. Theoretically the output of this amplifier circuit is as follows:

$V_{\text {Output }}=-\frac{R f}{R i n} x$ Vin

Where :

$\mathrm{Rf}=$ Feedback resistor (amounting to $20 \mathrm{k} \Omega$ )

Rin $=$ Resistor input (for $10 \mathrm{k} \Omega$ )

Vin $=$ Input voltage (equal to 1.24 Volt)

So that:

$V_{\text {Output }}=-\frac{20000}{10000} \times 1,24$

$=-2 \times 1,24$

$=-2,48$ Volt

Because the ADC only accepts positive voltage, then the second op-amp circuit with a configuration as 1-time gain will reverse the negative voltage polarity produced by the first opamp into a positive voltage of 2.48 Volt. From the test results and the calculation results there is an error of:

Error $(\%)=\frac{\text { calculation data-measurement data }}{\text { camculation data }} \times 100 \%$

$=\frac{2,48-2,48}{2,48} \times 100 \%$

$=0 \%$

b. The second test is carried out when the air conditioner is active and the compressor is off, where the current is 0.7 Ampere. The output of the current sensor that is carried out using a Volt meter (V1) measuring instrument is 2.62 Volt. Theoretically, the output voltage of the current sensor is equal to:

$\mathrm{V}_{\text {Output }}=2,5+(0,185 \mathrm{x} \mathrm{I})$

$=2,5+(0,185 \times 0,7)$

$=2,63$ Volt .

The amount of error between the calculation data and the test data is:

Error $(\%)=\frac{\text { calculation data-measurement data }}{\text { camculation data }} \times 100 \%$

$=\frac{2,63-2,62}{2,63} \times 100 \%$

$=0,4 \%$

Voltage testing is done by using a V2 measuring device at the output after passing through the voltage divider circuit and rectifier circuit showing the number 1.31 Volt. Theoretically the output voltage of the voltage divider circuit is as follows:

$V_{\text {Output }}=\frac{R 2}{R 2+R 1} \times$ vin

Where is the amount of $\mathrm{R} 1=\mathrm{R} 2=1 \mathrm{k} \Omega$, so that

$V_{\text {Output }}=\frac{1000}{1000+1000} \times 2,62$

$=0,5 \times 2,62$

$=1,31$ Volt .

The amount of error between the results of calculations and the test results is as follows:

$\operatorname{Error}(\%)=\frac{\text { calculation data-measurement data }}{\text { camculation data }} \times 100 \%$ $=\frac{1,31-1,31}{1,31} \times 100 \%$

$=0 \%$

Testing the voltage carried out using a V3 measuring device at the output after passing through the op-amp amplifier circuit shows a number of $2.62 \mathrm{Volt}$. Theoretically the output of this amplifier circuit is as follows:

$V_{\text {Output }}=-\frac{R f}{\operatorname{Rin}} \times \mathrm{Vin}$

Where :

$\mathrm{Rf}=$ Feedback resistor (amounting to $20 \mathrm{k} \Omega$ )

Rin $=$ Resistor input (for $10 \mathrm{k} \Omega$ )

Vin $=$ Input voltage (equal to 1.31 Volt)

So that:

$V_{\text {Output }}=-\frac{20000}{10000} \times 1,31$

$=-2 \times 1,31$

$=-2,62$ Volt

Because the ADC only accepts positive voltage, then the second op-amp circuit with a configuration as 1-time gain will reverse the negative voltage polarity produced by the first opamp into a positive voltage of 2.62 Volt. From the test results and the calculation results there is an error of:

Error $(\%)=\frac{\text { calculation data-measurement data }}{\text { camculation data }} \times 100 \%$

$=\frac{2,62-2,62}{2,62} \times 100 \%$

$=0 \%$

c. The third test is carried out when the air conditioner is active and the compressor is on to reach the appropriate temperature. with a set point, where the current is 1.7 Ampere. The output of the current sensor that is carried out using a Volt meter (V1) measuring instrument is 2.82Volt. Theoretically, the output voltage of the current sensor is equal to:

$\mathrm{V}_{\text {Output }}=2,5+(0,185 \times \mathrm{I})$

$=2,5+(0,185 \times 1,7)$

$=2,81$ Volt .

The amount of error between the calculation data and the test data is: $0 \%$

The voltage test carried out by using a V3 gauge at the output after passing through the op-amp amplifier circuit shows a number of 2.81 Volt. Theoretically the output of this amplifier circuit is as follows:

$$
\begin{aligned}
& V_{\text {Output }} \quad=-\frac{20000}{10000} \times 1,4 \\
& =-2 \times 1,4 \\
& =-2.8 \text { Volt }
\end{aligned}
$$

Because the ADC only accepts positive voltage, then the second op-amp circuit with a configuration as 1-time gain will reverse the negative voltage polarity produced by the first opamp into a positive voltage of 2.8 Volt. From the test results and the calculation results there is an error of:

$$
=\frac{2,8-2,81}{2,78} \times 100 \%
$$




\section{$=-0,35 \%$}

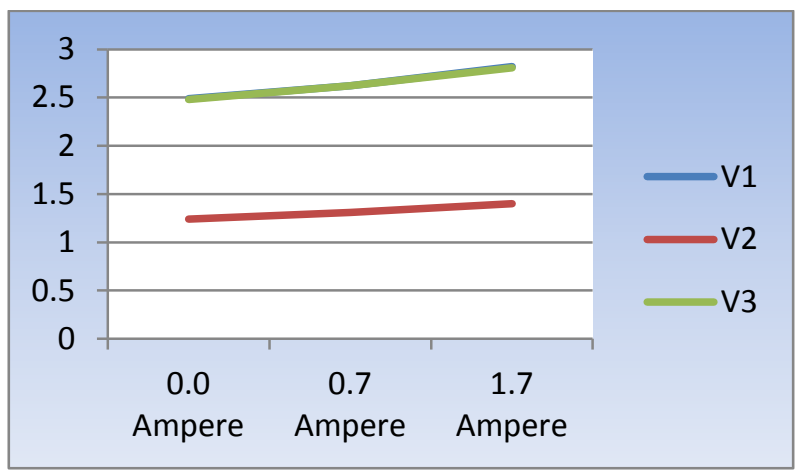

Fig 4: Voltage measurement chart for current

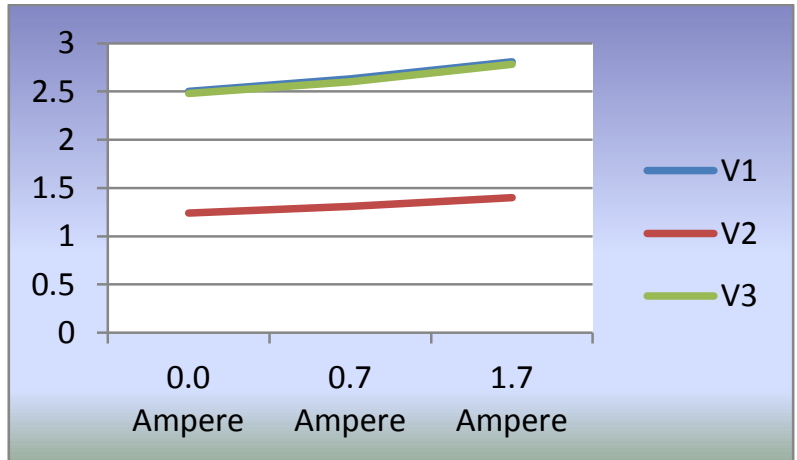

Fig 5: Graph of voltage calculation with current

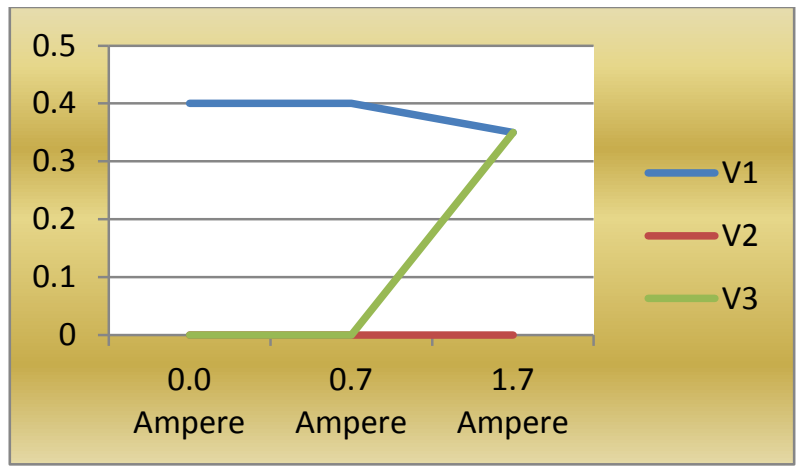

Fig 6: Error Graph

\section{CONCLUSIONS}

Based on the results of $70 \%$ of activities, it can be concluded as follows:Has produced hardware schematics from the 3 phase load balancing control system automatically to avoid power losses, through the stages of block diagram design, hardware design and hardware making by integrating it through a proteus simulation program that represents the system real control. Software has been produced for the work requirements of the 3-phase load balance control system to avoid power losses, through the stages of software design in the form of flow diagrams and program creation through Arduino IDE. The remaining work to be done is $30 \%$ which includes installing the generated program into the Arduino Uno controller in the proteus program simulation, then testing the functional work of the 3 phase load balance control system automatically to avoid power losses, to get data related to the work function of the control system.

\section{ACKNOWLEDGMENT}

Thanks to the Ministry of Research and Technology and Higher Education and manado state polythecnic, which has funded this research with competitive grants program in 2018 so as to do research and work well.

\section{REFERENCES}

[1] Budiharto, W, Interfacing Komputer dan Mikrokontroller, Elex Media Komputindo, Jakarta, 2004.

[2] Fanny Jouke Doringin, .Sistem Kendali Penyeimbang Beban Tiga Fasa Pada Jaringan Distribusi. Tesis 2010

[3] Stephy Beatrix Walukow, Sistem Kendali Jalur Fasa Pada KWH Meter Pelangan Listrik Daya Besar. Tesis UNHAS, 2010

[4] I Wayan Suwardana, I Putu Sutawinaya dan I Ayu Rai Wulandari ,Studi Analisis Rugi-Rugi Daya pada Penghantar Netral Akibat Sistem Tidak Seimbang di Jaringan Distribusi Gardu KA 1495 Penyulang Citraland Menggunakan Simulasi Program ETAP 7.0. JURNAL LOGIC. VOL. 14. NO. 3. NOPEMBER 2014

[5] Hanny H. Tumbelaka, Thian, Marselin, Aplikasi Active Power Filter Tiga Fasa Tipe Seri Berbasis Jaringan Syaraf Tiruan Untuk Mengatasi Sumber Tegangan Yang Terdistorsi, ITS,

[6] Peng F. Z, Harmonic sources and filtering approaches, Industry Applications Magazine, IEEE, 2001 7(4): p.1825 .

[7] Green, T.C. and J.H, Marks, Control techniques for active power filters, Electric Power applications, IEEE Proceedings, 2005, 152(2):pp.369-381.

[8] Temurtas, F., et al., Harmonic detection using feed forward and recurrent neural networks for active filte, Electric Power Systems Research, 2004, 72(1): pp. 3340 .

[9] Insan Hakim Maliki Priangga, Analisa Ketidakseimbangan Beban Terhadap Rugi-Rugi Daya Pada Saluran Dan Transformator Distribusi 20kv (Studi Kasus Pada Penyulang Badai Di Gardu Induk Teluk Betung), Skripsi, Universitas Lampung, 2016

[10] Setiatmoko Adi Prakoso, Iwa Garniwa M.K, Analisis Pengaruh Harmonik Terhadap Arus netral Transformator Pelanggan Industri, Bisnis dan Rumah Tangga, Universitas Indonesia 2014

[11] Ahmad Deni Mulyadi, "Pengaruh Ketidakseimbangan Beban Terhadap Arus Netral dan Losses Pada Trafo Distribusi," Metrik Polban, [online], vol 5, no 1, 24-28, 2011. http://jurnal.polban.ac.id/index.php/mesin/article/ download/23/20. (Accesed : 8 juni 2014)

[12] Ronny Katuuk, Marson James Budiman and Donald B Noya. Application of Fuzzy Logic Algorithm for Hybrid Car Usage Time. International Journal of Computer Applications 181(21):1-4, October 2018. 